\title{
Effect of Mariculture on bio-optical properties and water quality of Gulf of Mannar and Palk Bay
}

\author{
Shaju S.S. ${ }^{\text {a,* }}$, Sreekutty C. Prasad ${ }^{\text {b }}$, Vishnu P.S. ${ }^{c}$, Amir Kumar Samal ${ }^{\mathrm{d}}$, Nandini Menon ${ }^{\mathrm{a}}$, \\ Nashad M. ${ }^{e}$, K. Avarachen Mathew ${ }^{\mathrm{f}}$, A.K. Abdul Nazar ${ }^{\mathrm{d}}$, Grinson George ${ }^{\mathrm{g}}$ \\ a Nansen Environmental Research Centre (India) (NERCI), 6A Oxford Business Centre, Kochi - 682016, India \\ ${ }^{\mathrm{b}}$ Department of Fishery Hydrography, School of FRMEHT, KUFOS, Kochi - 682056, Kerala, India \\ c SPECTRAL Remote Sensing Laboratory, University of Victoria, 3800 Finnerty Rd, Victoria, BC V8P 5C2, Canada \\ ${ }^{\mathrm{d}}$ Mandapam Regional Centre, Central Marine Fisheries Research Institute, Mandapam, India \\ e Fishery Survey of India, Port Blair Base, Phoenix Bay Jetty PB-744101 Andaman and Nicobar Islands, India \\ ${ }^{\mathrm{f}}$ Department of Biology Norwegian University of Science and Technology (NTNU), Trondheim, Norway \\ ${ }^{g}$ ICAR-Central Marine Fisheries Research Institute, Cochin, India
}

\section{H I G H L I G H T S}

- This study presents the first in-situ bio-optical data for the Coastal Waters Gulf of Mannar and Palk Bay.

- High temporal and spatial variability in the absorption components were observed in the present work.

- The biogeochemistry and phytoplankton biomass of the effect of Trichodesmium bloom on the Coastal Waters Gulf of Mannar and Palk Bay were studied.

\section{A R T I C L E I N F O}

\section{Article history:}

Received 1 September 2017

Received in revised form 20 March 2019

Accepted 3 April 2019

Available online 12 April 2019

\section{Keywords:}

Algal bloom

Mariculture

Trichodesmium

Bio-optical properties

Gulf of Mannar

\begin{abstract}
A B S T R A C T
Marine cage aquaculture is gaining importance in India, due to its contribution as an alternate livelihood to coastal communities and also because of its export value. Water quality is the most important determinant for sustainable marine cage farming. Nutrient enrichment in coastal waters results in increased occurrence of algal blooms. A mariculture practice makes the coastal waters eutrophic due to increased input of nitrogen and phosphorous, ultimately leading to bloom. A phytoplankton bloom dominated by Trichodesmium species was detected outside mariculture cages located in Gulf of Mannar during August, 2015, which possibly interfered with fish gill function. High nutrient and chlorophyll $a$ (Chl-a) $\left(29.97 \mathrm{mg} / \mathrm{m}^{3}\right)$ concentration were observed during peak bloom period. Three groups of phytoplankton were identified - diatoms ( 24 species with, 14 centric species and 10 pennate species), dinoflagellates (10 species) and cyanobacteria (one species). Stable salinity condition and the depletion in nutrient concentration due to higher primary production might have triggered the bloom of Trichodesmium. In-situ bio-optical measurements were also made to understand the spatial and temporal variation and effect of bloom on the optical components. Our study is a preliminary step to understanding the in-situ bio-geochemical and bio-optical characteristics of coastal waters of Gulf of Mannar and Palk Bay, which could aid in the management of cage culture sites.
\end{abstract}

(C) 2019 Elsevier B.V. All rights reserved.

\section{Introduction}

Mariculture activities are promoted quoting their successful role in meeting the greater demand for seafood. However, mariculture can modify a habitat, change trophic systems, reduce natural seed stock, transmit diseases and reduce genetic variability (ICES, 2002; Mires, 1999). Nutrient discharge from mariculture effluent could induce algal blooms in coastal waters (Davidson

\footnotetext{
* Corresponding author.

E-mail address: shaju.peringammala@gmail.com (S.S. Shaju).
}

et al., 2014). Phytoplankton is the source of organic production in coastal waters. Therefore, information on their biomass, composition and community structure are key components in environmental monitoring (Paerl et al., 2003). Under optimum conditions, many species of phytoplankton proliferate rapidly, and coastal currents, temperature, salinity fronts, nutrients and anthropogenic drivers contribute to the formation of algal blooms. Mariculture activities in coastal waters are becoming a concern worldwide, because it may contribute to nutrient enrichment or eutrophication causing algal blooms (Cloern, 2001; Anderson et al., 2008; Tett et al., 2008; Karydis and Kitsiou, 2013). The harmful effects of blooms may linger even when a bloom is not 
physically visible (Galloway et al., 2004). Harmful and toxic algal blooms near the mariculture sites result in mortality of farmed fish due to poisoning, or gill damage or growth impairment (Beveridge, 2004; Davidson et al., 2009; Borg, 2011). Early warning of algal blooms using remote sensing data will be useful for salvaging farmed fish.

Monitoring of mariculture sites using remote sensing could be successful only after thorough validation with in situ data, as the coastal waters are optically complex (Vishnu et al., 2018). Assessment of in-situ phytoplankton and their optical properties in the coastal waters can generate database required to develop regional bio-optical algorithms for retrieving chlorophyll $a$ (Chl-a) from satellite remote sensing data (Lee et al., 2011). Information on bio-optical measurements from the western and eastern coastal waters of India are available (Menon et al., 2011; Tilstone et al., 2013; Shaju et al., 2015; Vishnu et al., 2018; Pandi et al., 2013, 2017), but no reports from the Gulf of Mannar, where cage mariculture is very popular. In this study an attempt was made to analyse the biogeochemistry, bio-optical properties and phytoplankton composition during and after a phytoplankton bloom at a prominent mariculture site in the coastal waters of Gulf of Mannar, east coast of India.

\section{Study area}

Gulf of Mannar and Palk Bay (Fig. 1) located in the southeast coast of India, are less productive during the northeast monsoon season (October to December) due to increased turbidity and cloud cover (Bindu and Muniyandi, 2005). Rameshwaram Island, surrounded by Palk Bay and Gulf of Mannar on either sides, acts as a physical barrier, limiting water and sediment exchange between the two water bodies. During the withdrawal phase of the summer monsoon (June to September), lower level winds over south Asia reverse their direction from southwest to northeast. These seasonally reversing monsoon winds over the north Indian Ocean force a seasonally reversing circulation in the upper ocean (Shankar et al., 2002). South west monsoon does not bring much rain to this coast, whereas north east monsoon brings heavy rainfall to this area. The tidal amplitude is about $0.75 \mathrm{~m}$ during the south west monsoon. The coastal waters of Gulf of Mannar become turbulent owing to strong winds (Jyothibabu et al., 2013). The hydrography of the Palk Bay is significantly influenced by Bay of Bengal waters, whereas Gulf of Mannar waters are influenced by the Arabian Sea. India's first marine biosphere reserve is situated in this region which is an important feeding ground for the vulnerable marine mammal Dugong, endangered green turtles and Olive Ridley turtles (Ramachandran et al., 2000). Due to the absence of fresh water discharge from any other perennial river, coastal waters around Rameswaram region has relatively low land drainage and terrestrial runoff (Baskar et al., 2015).

\section{Data and methods}

Sampling was conducted in the vicinity of the culture cages situated near to the coast in Gulf of Mannar ( $\mathrm{C} 1$ and 01 ), point location in Gulf of Mannar away from the culture sites (G1) and a reference station in Palk Bay (P1) during the months July and August 2015 onboard the Central Marine Fisheries Research Institute (CMFRI) vessel. Sampling stations are shown in Fig. 1 and details of the stations are given in Table 1 . Satellite daily mean chlorophyll a $(4 \mathrm{~km} \times 4 \mathrm{~km} \times 4 \mathrm{~km})$ and modelled Sea surface Temperature (SST) and Sea surface salinity (SSS) data $\left(0.083^{\circ} \times 0.083^{\circ}\right)$ were taken from the Ocean products provided freely by the EU Earth observation programme Copernicus (www. marine.copernicus.eu). Water samples collected were analysed

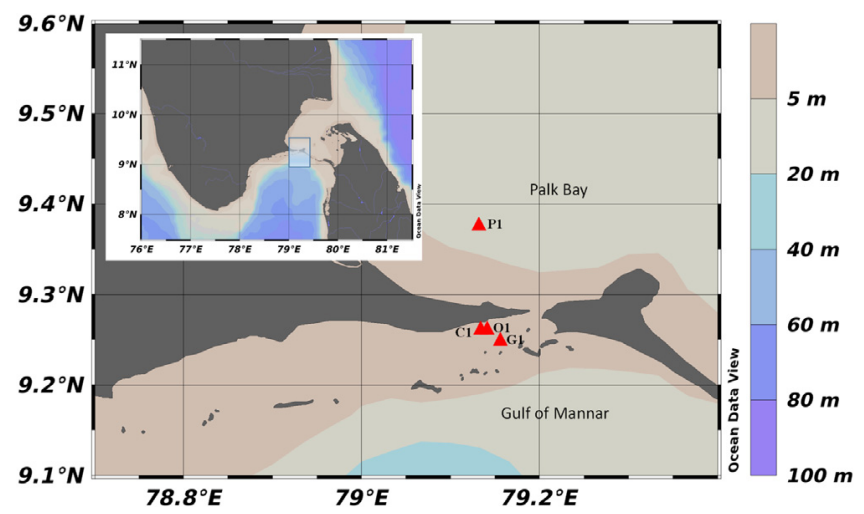

Fig. 1. Map of the in-situ sampling locations in the Gulf of Mannar and Palk Bay showing the sampling points (triangular markings).

for salinity, nitrite $\left(\mathrm{NO}_{2}\right)$, nitrate $\left(\mathrm{NO}_{3}\right)$, phosphate $\left(\mathrm{PO}_{4}\right)$ and silicate $\left(\mathrm{SiO}_{4}\right)$ as per standard protocols (Grasshoff et al., 1999).

Chl-a was measured using a field fluorometer (model: 10-AU; Turner designs, Sunnyvale, C.A. USA) following the Welschmeyer method (Welschmeyer, 1985). Water samples (0.1 to $1.0 \mathrm{l}$ ) were filtered through $25 \mathrm{~mm}$ glass fibre filters $(\mathrm{GF} / \mathrm{F})$ and extracted overnight in $90 \%$ acetone. The samples were then centrifuged for $10-20 \mathrm{~min}$ at $2000 \mathrm{rpm}$ and the raw fluorescence given as digital volts was converted to Chl-a concentrations using calibration curves from Chl-a standards (Sigma-Aldrich Company Ltd., St. Louis, MO, USA). Satlantic hyperspectral radiometer (Hyper OCRII) was operated at all the stations except at station P1 (Palk Bay) in August. The instrument is equipped with ancillary sensors for measuring tilt, pressure, temperature and conductivity. The Coloured Dissolved Organic matter (CDOM) fluorescence was measured using ECO triplet sensor in the instrument (WetlabsTM ECO series). The excitation and emission wavelengths to measure CDOM fluorescence were 370 and $460 \mathrm{~nm}$ respectively with a sensitivity of $0.28 \mathrm{ppb}$ of quinine sulphate dihydrate equivalent (QSDE).

\subsection{Analysis of spectral absorption coefficient of phytoplankton}

Seawater samples (2-5 1) collected from each station using 2.51 (General Oceanic, USA) Niskin bottle sampler were transferred, to polyethylene filtration bottles. The water samples were filtered under low vacuum $(<25 \mathrm{hPa})$ through $25 \mathrm{~mm}$ Whatman GF/F filters. The light absorption spectrum of phytoplankton was measured by the quantitative filter technique (QFT) method (Mitchell and Holm-Hansen, 1991). The absorption spectra of total particulate matter relative to a blank filter saturated with sea water were recorded in the wavelength range $400-750 \mathrm{~nm}$ at $1 \mathrm{~nm}$ intervals with a double-beam spectrophotometer equipped with an integrating sphere (Mitchell et al., 2003). For each of the measured spectra, the optical density obtained at $750 \mathrm{~nm}$ was subtracted from all other wavelengths. Optical density of the total suspended matter was corrected for the path length amplification ( $\beta$ effect) and converted into light absorption coefficients by the total particulate matter and detrital matter $\left(a_{\mathrm{p}}(\lambda)\right.$ and $a_{\mathrm{d}}$ $(\lambda)$ respectively (Cleveland and Weidemann, 1993; Kyewalyanga et al., 1998)

$a_{\mathrm{p}}(\lambda)=\frac{2.303[\mathrm{ODp}]_{\mathrm{S}}(\lambda)}{\mathrm{V} / \mathrm{S}}$
$[\mathrm{ODp}]_{\mathrm{s}}(\lambda)=0.378 \mathrm{OD}_{\mathrm{f}}(\lambda)+0.523\left[\mathrm{OD}_{\mathrm{f}}(\lambda)\right]^{2}$

where $[\mathrm{ODp}]_{S}(\lambda)$ is the optical density of total suspended particulate matter, $\mathrm{V}$ is the filtration volume $\left(\mathrm{m}^{3}\right)$ and $\mathrm{S}$ is the 
Table 1

Details of sampling sites selected for the study.

\begin{tabular}{|c|c|c|c|c|}
\hline \multirow[t]{2}{*}{ Station name } & \multirow[t]{2}{*}{ Description of the region of sampling } & \multirow[t]{2}{*}{ Sampling date } & \multicolumn{2}{|c|}{ Sampling positions } \\
\hline & & & Latitude & Longitude \\
\hline $\mathrm{C} 1$ & Inside fish culture cage & $\begin{array}{l}\text { 1st July } 2015 \\
\text { 4st Aug } 2015\end{array}$ & $9^{\circ} 16^{\prime} 11^{\prime \prime}$ & $79^{\circ} 07^{\prime} 44^{\prime \prime}$ \\
\hline 01 & Outside fish culture cage & $\begin{array}{l}\text { 1st July } 2015 \\
4,5 \& 6 \text { Aug } 2015\end{array}$ & $9^{\circ} 16^{\prime} 07^{\prime \prime}$ & $79^{\circ} 07^{\prime} 41^{\prime \prime}$ \\
\hline G1 & Gulf of Mannar & $\begin{array}{l}\text { 2nd July } 2015 \\
\text { 6th Aug } 2015\end{array}$ & $9^{\circ} 15^{\prime} 20^{\prime \prime}$ & $79^{\circ} 10^{\prime} 07^{\prime \prime}$ \\
\hline P1 & Palk Bay & 2nd July 2015 & $9^{\circ} 23^{\prime} 54^{\prime \prime}$ & $79^{\circ} 08^{\prime} 42^{\prime \prime}$ \\
\hline
\end{tabular}

filtration area $\left(\mathrm{m}^{2}\right)$. Following the measurement of the total particulate absorption spectrum, the filters were extracted in $100 \%$ methanol following the procedure of Kishino et al. (1985). After this extraction, the absorption spectra of the filters relative to blank filters treated with methanol and re-saturated with filtered seawater were recorded in the range 400-750 nm using a double-beam spectrophotometer equipped with integrating sphere. These spectra represent absorption by non-methanol extractable detrital matter.

$a_{\mathrm{d}}(\lambda)=\frac{2.303[\mathrm{ODd}]_{\mathrm{S}}(\lambda)}{\mathrm{V} / \mathrm{S}}$

where $[\mathrm{ODd}]_{S}(\lambda)$ is calculated using the same equation as above. The term ' $V$ ' and ' $S$ ' stands for the filtration volume $\left(\mathrm{m}^{3}\right)$ and filtration area $\left(\mathrm{m}^{2}\right)$ respectively. An estimate of phytoplankton component $\left(a_{\mathrm{ph}}(\lambda)\right)$ from the total particulate absorption was then determined by subtracting $a_{\mathrm{d}}(\lambda)$ from $a_{\mathrm{p}}(\lambda)$ (Kishino et al., 1985)

$a_{\mathrm{ph}}(\lambda)=a_{\mathrm{p}}(\lambda)-a_{\mathrm{d}}(\lambda)$

The chlorophyll-specific light absorption coefficients of phytoplankton $\left(a_{\mathrm{ph}}^{*}(\lambda)\right)$ were obtained by normalizing the $a_{\mathrm{ph}}(\lambda)$ values with Chl-a concentration.

\subsection{Remote-sensing reflectance}

Remote-sensing reflectance $\left(R_{\mathrm{rs}}\right)$ in hyperspectral bands were measured using the Satlantic ${ }^{\mathrm{TM}}$ hyperspectral radiometer (Hyper OCRII). This instrument contains 256 optical channels between 350 and $800 \mathrm{~nm}$ that measure downwelling surface irradiance $\left(E_{\mathrm{S}}\right)$ and profiles of downwelling irradiance $\left(E_{\mathrm{d}}\right)$ and upwelling radiance $\left(L_{\mathrm{u}}\right)$. The radiometers were deployed away from the vessel to avoid ship-induced perturbations and shading (Fargion and Mueller, 2000). The data were recorded using SatView ${ }^{\mathrm{TM}}$ software and processed with Prosoft ${ }^{\mathrm{TM}}$ software. When the tilt of the sensor was more than $5^{\circ}$ and profiling velocity was more than $0.7 \mathrm{~m} \mathrm{~s}^{-1}$, the data were discarded to ensure a high quality for measurements. The $R_{\mathrm{rs}}(\lambda)$ was then calculated from the equation:

$R_{r s}(\lambda)=\frac{L_{\mathrm{w}}\left(\lambda, 0^{+}\right)}{\mathrm{E}_{\mathrm{d}}\left(\lambda, 0^{+}\right)}$

Where $E_{\mathrm{d}}\left(\lambda, 0^{+}\right)$is the above-surface downwelling spectral irradiance $\left(\mathrm{Wm}^{-2} \mathrm{~nm}^{-1}\right)$ and $L_{\mathrm{w}}\left(\lambda, 0^{+}\right)$is the water-leaving radiance just above the sea surface $\left(\mathrm{Wm}^{-2} \mathrm{~nm}^{-1} \mathrm{sr}^{-1}\right)$. Standard ocean optics protocols (Fargion and Mueller, 2000) were used in the computation of water leaving radiance $\left(L_{\mathrm{w}}\right)$.

\section{Results and discussion}

\subsection{Phytoplankton composition}

Phytoplankton community structure of the present study area are scarcely studied (Yapa, 2000; Rao et al., 2008; Sridhar et al.,
2010). We have observed that in July, centric diatoms like Coscinodiscus, Rhizosolenia, Bacteriastrum and Thalassiosira occurred in most stations. Among pennate diatoms, Pleurosigma was common in all stations. Ceratium and Dinophysis were the most common dinoflagellates in all stations. Trichodesmium, the lone cyanobacteria identified was present in all stations except P1. During August, the changes observed were with respect to pennate diatoms, where Navicula also was found commonly in all stations. In addition to Ceratium, other dinoflagellates like Paralia, Protoperidinium and Pyrophacus were common in all stations. All stations had representation by the cyanobacterial species, Trichodesmium, which exhibited very intense bloom. The percentage composition of phytoplankton groups in the different stations during July and August are shown in Fig. 2. A total of 35 species of phytoplankton from 13 orders and 26 families were identified, which fell into three groups - diatoms (24 species with, 14 centric species and 10 pennate species), dinoflagellates (10 species) and cyanobacteria (one species). Throughout the study period centric diatoms dominated in this area except blooming period. They are known for their fast growth in response to nutrient enrichments (Harrison and Davis, 1979) and often dominate in eutrophic waters. Pennate diatoms generally have lower growth rates than the centric species (Grover, 1989). During July, diatoms were dominant over dinoflagellates and cyanobacteria except the station outside fish culture cage, where dinoflagellates were dominant. Cyanobacteria was completely absent in Palk Bay. During August, there was a bloom by Trichodesmium, wherein the only phytoplankton during the bloom and declining period of the bloom was this cyanobacteria. Phytoplankton studies using fluorescence microscopy and flow-cytometry have shown the occurrence of autotrophic pico-eukaryotes and nanoplankton communities in Gulf of Mannar, and cyanobacteria (Synechococcus) (potential contributor to $\mathrm{HAB}$ ) and heterotrophic nanoplankton in Palk Bay waters (Jyothibabu et al., 2013). Diazotrophic cyanobacteria that already exists in the waters might have proliferated to bloom dimensions due to the sudden nutrient depletion in the waters. Oligotrophy caused by nutrient and light limitation is considered to be the major ecological driver in the Bay of Bengal (Jyothibabu et al., 2008; Mitbavkar and Anil, 2011). Most cyanobacteria stay near the surface of the water and have mechanisms such as gas vesicles to control their buoyancy. They can adjust buoyancy with light and nutrient levels during the day, but at night they may float to the surface, creating the impression of a sudden bloom appearance. Even though Trichodesmium is not considered as a toxic species, clogging of the gills led to mortality of fishes in the cages. So, early detection of bloom is a necessity for preventing economic loss.

\subsection{Variability of physico-chemical parameters}

The salinity of water sample collected from study area varied from 33.84 to 35.71 psu. Salinity was high, $>35$ psu in most stations in July. Only station P1 showed comparatively lower salinity, 33.84 psu. Vinayachandran et al. (2005) and Jagadeesan et al. (2013) have proved that Arabian Sea High Saline Water 


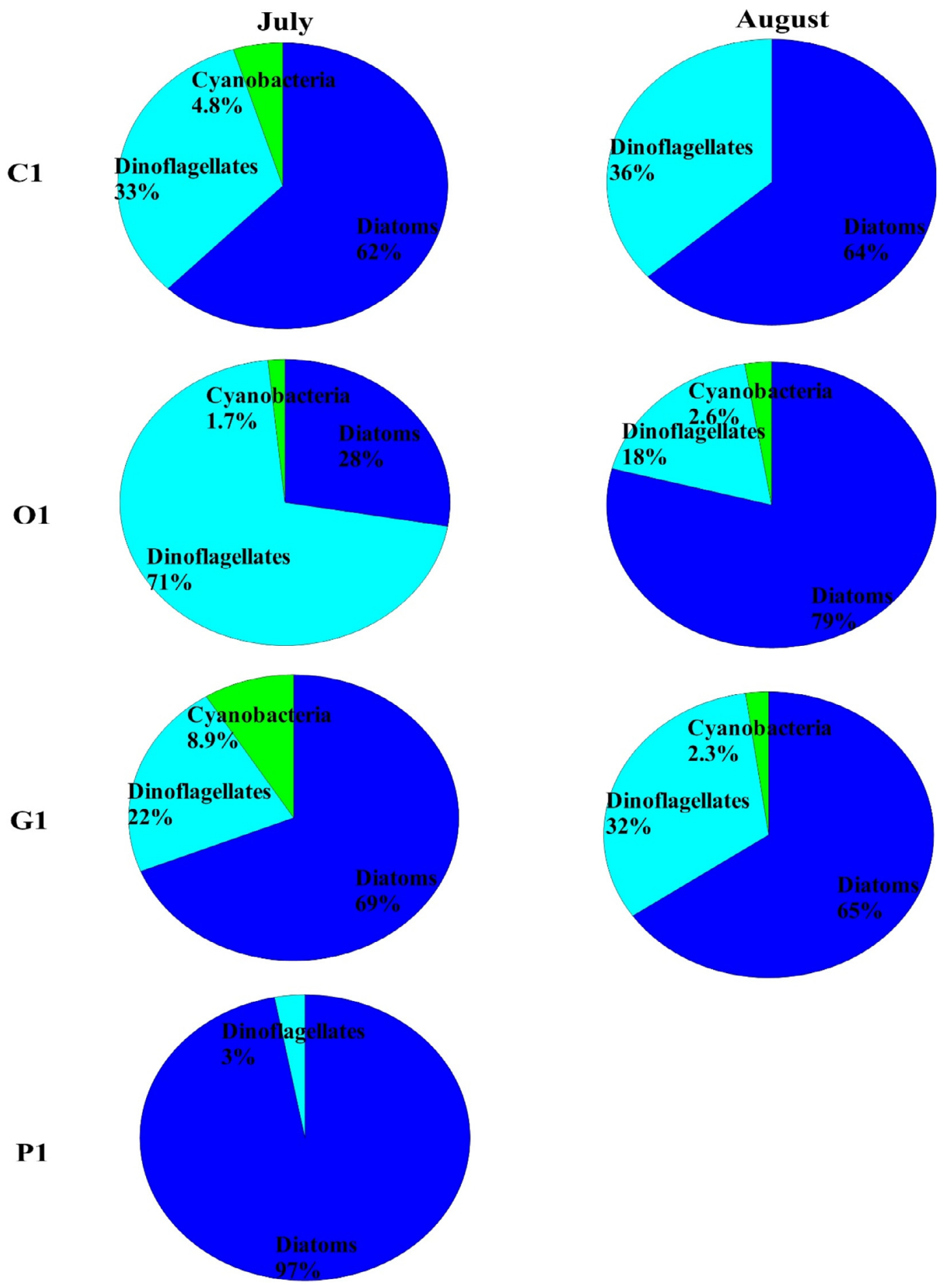

Fig. 2. Percentage of phytoplankton groups at stations $\mathrm{C} 1,01, \mathrm{G} 1$ and P1 in July and in August after the bloom by Trichodesmium..

(ASHSW) mass reaches the Gulf of Mannar through West India Coastal Current (WICC) during the southwest monsoon (JuneSeptember). Fig. 3a and b that show increase in the salinity and decrease in the SST during June to September corroborate this view. The satellite chlorophyll a concentration for one year is shown in the Fig. 3c. In August, salinity was above 35 psu at all stations which was due to the dissemination of ASHSW to even the Palk Bay region due to water exchange between the Palk Bay and the Gulf of Mannar (Jagadeesan et al., 2013). Purvaja et al. (2018) have also reported that the salinity in this region ranged from 32.4 to 37.3 psu during dry season and 33.1 to 35.6 psu in wet season.

In July nitrite varied from 0.929 to $1.63 \mu \mathrm{mol} \mathrm{l}^{-1}$, nitrate varied from 0.389 to $0.64 \mu \mathrm{mol} \mathrm{l}^{-1}$, phosphate varied from 0.011 to $2.293 \mu \mathrm{mol} \mathrm{l}^{-1}$ and silicate varied from 0.0524 to $0.314 \mu \mathrm{mol}$ $1^{-1}$. Station 01 showed comparatively high amount of nutrients except silicate whereas G1 showed comparatively low level of nutrients. During peak bloom in August, the nutrient levels were very high at station 01- $6.019 \mu \mathrm{mol} \mathrm{l}^{-1}, 14.009 \mu \mathrm{mol} \mathrm{l}^{-1}$, 
LONGITUDE : $79.1 E$ to $79.2 E(X Y$ ave $)$

LATITUDE : $9.2 \mathrm{~N}$ to $9.4 \mathrm{~N}$ (XY OVe)

LATITUDE : $9.2 \mathrm{~N}$ to

DATA SET: temperature_salinity

daily mean fields from Global Ocean Physics Analysis and Forecast updated Daily

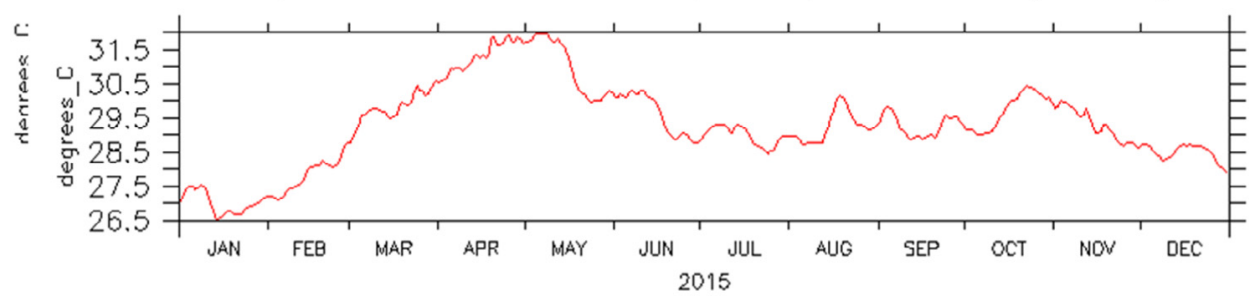

Temperature

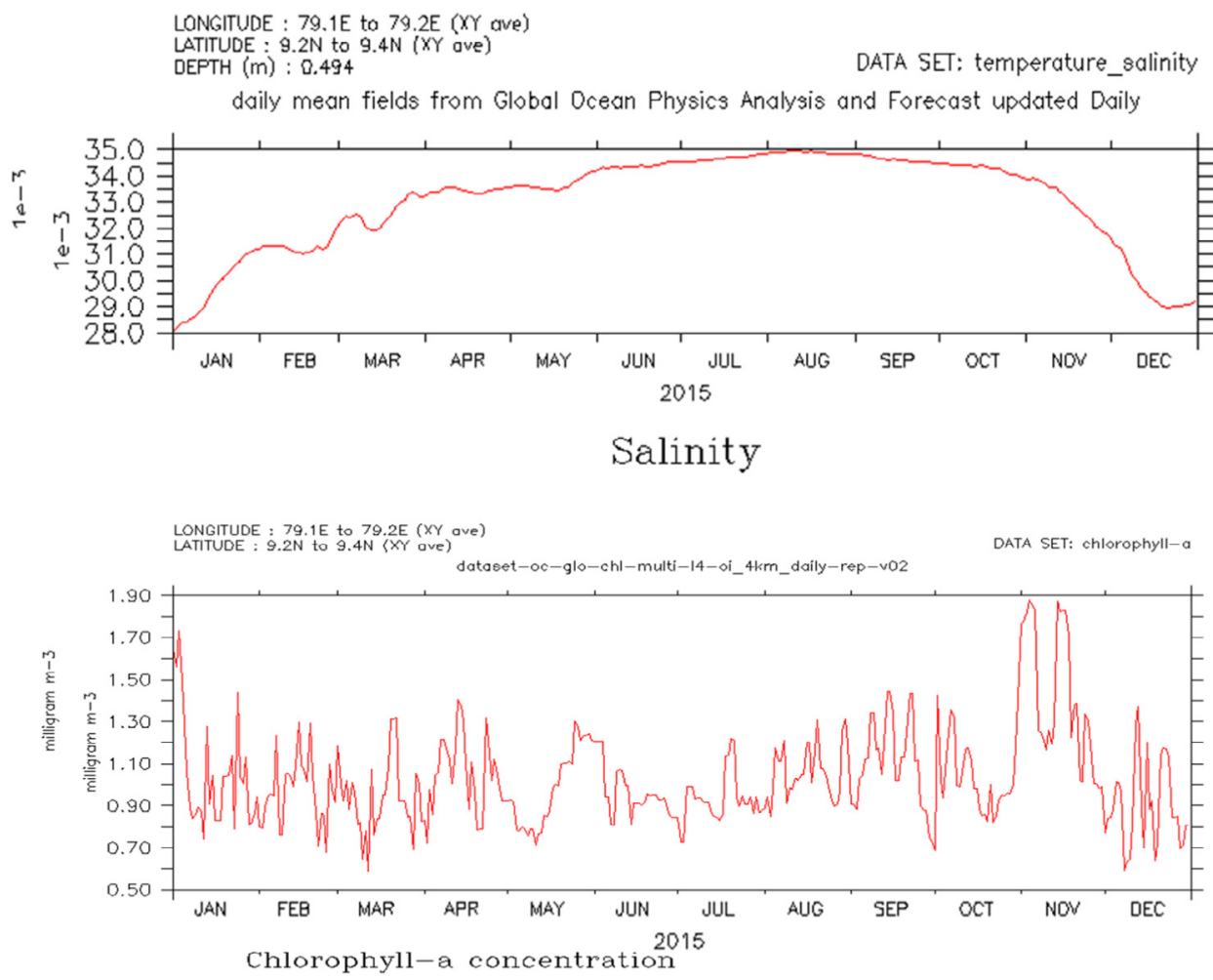

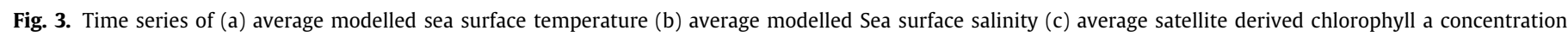
around the Gulf of Mannar and Palk Bay region $\left(79.1^{\circ} \mathrm{E}-79.2^{\circ} \mathrm{E}, 9.2^{\circ} \mathrm{N}-9.4^{\circ} \mathrm{N}\right)$ for the year 2015.

$4.306 \mu \mathrm{mol} \mathrm{l}^{-1}$ and $15.312 \mu \mathrm{mol} \mathrm{l}^{-1}$ for nitrite, nitrate, phosphate and silicate respectively. After the bloom the nutrient levels dropped to $0.074 \mu \mathrm{mol} \mathrm{l}^{-1}, 0.562 \mu \mathrm{mol} \mathrm{l}^{-1}, 0.748 \mu \mathrm{mol} \mathrm{l}^{-1}$, and $1.415 \mu \mathrm{mol} \mathrm{l}^{-1}$ for nitrite, nitrate, phosphate and silicate respectively. It is reported that nutrient concentrations in Palk Bay vary spatially and temporally with a distinct change in $\mathrm{N}$ : $\mathrm{P}$ ratios between dry (3.5:1) and wet (13:1) seasons, indicating intense nitrogen limitation during dry season (Purvaja et al., 2018). A gradual increase in salinity was noticed during August in Palk Bay. Stable high salinity condition close to typical value of $35 \mathrm{psu}$ along with the nitrogen deficiency in the water column supported the growth and abundance of Trichodesmium. It is well known that the cyanobacterium is a stenohaline form with optimum growth at salinity $>33$ psu (Mohanty et al., 2010).

During July, CDOM was in the range of 1.7 to $2.6 \mathrm{ppb}$ QSDE, whereas during August after the bloom it reduced to 1.42-2.4 ppb QSDE. Station 01 showed high CDOM concentration (2.4 ppb QSDE) whereas station G1 had low CDOM (1.42 ppb QSDE) content. Palk Bay stations showed comparatively lower CDOM fluorescence values during July, whereas that inside the fish culture cage was high during August. CDOM variation is dependent on various sources such as fish excreta, wastes from fish feed and terrestrial sources (Zhao et al., 2009). As salinity of Palk Bay during July was low compared to other stations, the source of CDOM can be associated with fresh water influx. High CDOM concentration inside the cages can be attributed to the water stagnation inside the cages with higher residence time of excretory wastes and fish wastes in the cage. The leaching of this organic matter out of the fish culture cage is reflected in the CDOM value outside the fish culture cage (1.920 ppb QSDE). Purvaja et al. (2018) have reported that Palk Bay had a marginally increased concentration of suspended particulate matter and higher input of sediments from land based sources during the wet season. Sedimentation rate at Mandapam area is nearly $38.54 \mathrm{mg} \mathrm{cm}^{-2} \mathrm{~d}^{-1}$ during monsoon season.

In this study a large variation was found in Chl-a concentration. During July Chl-a concentration at station 01 was $2.03 \mathrm{mg}$ $\mathrm{m}^{-3}$, whereas Station P1 had a Chl-a concentration of $1.2 \mathrm{mg}$ $\mathrm{m}^{-3}$ only. Chl-a increased to $29.97 \mathrm{mg} \mathrm{m}^{-3}$ during peak bloom 
period at 01 which dropped to $1.698 \mathrm{mg} \mathrm{m}^{-3}$ during declining period of bloom. At station G1, Chl-a concentration showed a decrease from $1.45 \mathrm{mg} \mathrm{m}^{-3}$ to $0.54 \mathrm{mg} \mathrm{m}^{-3}$ during July to August. Inside the cage (station $\mathrm{C} 1$ ), the Chl-a concentration varied from 1.88 to $0.75 \mathrm{mg} \mathrm{m}^{-3}$. Comparing both months, July (1.2-2.03 $\left.\mathrm{mg} \mathrm{m}^{-3}\right)$ showed higher Chl-a content than August $(0.3-0.7 \mathrm{mg}$ $\mathrm{m}^{-3}$ ). After bloom, outside of mariculture cage (station 01), the Chl-a concentration dropped to $0.313 \mathrm{mg} \mathrm{m}^{-3}$. The Chl-a content was in agreement with the fluctuation in phytoplankton diversity at the different stations. Favourable environmental conditions might be the reason for the increased primary production in July and this caused the depletion of nutrients and along with this, the stable salinity condition triggered the Trichodesmium bloom (Mohanty 2010; (Murtugudde et al., 1999). During peak bloom period, nitrogen compounds showed large increase in concentration up to $6.019 \mu \mathrm{mol} \mathrm{l}^{-1}$ of nitrite and $14.009 \mu \mathrm{mol} \mathrm{l}^{-1}$ of nitrate. Trichodesmium is a diazotrophic cyanobacteria and can fix nitrogen aerobically during day time and it is a major source of nitrogen for marine ecosystems. This input may even exceed the input from river runoff (Kumar et al., 2010), which would have reflected in the high nutrient concentration during the bloom.

\subsection{Remote-sensing reflectance $\left(R_{r s}\right)$ and chlorophyll specific $a b-$ sorption coefficient of phytoplankton $\left(a_{p h}^{*}\right)$}

The measured in-situ Remote-sensing reflectance $\left(R_{\mathrm{rs}}\right)$ in the study area during July and August are shown in the Fig. 4a \& b. In July, $R_{\mathrm{rs}}$ spectra had a higher magnitude at station 01 and low magnitude at station C1, with sharp peaks around 540$550 \mathrm{~nm}$; whereas in August, the situation reversed and at station 01, the $R_{\mathrm{rs}}$ spectrum showed a flattened and wider peak that spanned from 500 to $560 \mathrm{~nm}$. The flattening could directly be related to the presence of mineral particles (Zhang et al., 2014; Lubac and Loisel, 2007). $R_{\mathrm{rs}}$ spectra of all stations except P1 were characterized by high Chl-a and CDOM absorption dominating at short wavelengths. At station P1, higher reflectance at red region indicated occurrence of total suspended particulate matter dominated by the mineral fraction and the rest by non-living particles (Minu et al., 2014).

During July, chlorophyll-specific light absorption coefficient of phytoplankton $\left[a^{*}{ }_{\mathrm{ph}}(\lambda)\right]$ varied from 0.06 to $0.031 \mathrm{mg} \mathrm{m}^{-2}$ and 0.006 to $0.01 \mathrm{mg} \mathrm{m}^{-2}$ at $440 \mathrm{~nm}$ and $665 \mathrm{~nm}$ respectively. The chlorophyll-specific light absorption coefficient of phytoplankton $\left[a_{\mathrm{ph}}^{*}(\lambda)\right]$ spectra of the study area for July and August are shown in the Fig. 4c \& d. Although Trichodesmium is detected easily by in situ observation in the tropical seas, it has been difficult to detect it remotely by satellites making the in-situ observation very important. In August, during peak bloom at station 01, the $a_{\mathrm{ph}}^{*}(440)$ was $0.026 \mathrm{mg} \mathrm{m}^{-2}$, which increased during the bloom senescence to $0.028 \mathrm{mg} \mathrm{m}^{-2}$ and again increased to a value of $0.109 \mathrm{mg} \mathrm{m}^{-2}$ after the bloom. The same pattern was observed at wavelength $665 \mathrm{~nm}$ with values ranging from 0.01 to 0.011 to $0.021 \mathrm{mg} \mathrm{m}^{-2}$. During August, $\mathrm{a}_{\mathrm{ph}}^{*}(\lambda)$ values showed higher values than the bloom stations and observed a non linearity between $a^{*}{ }_{\mathrm{ph}}(\lambda)$ and Chl-a. The general trend of $\mathrm{a}^{*}$ ph values is to increase with decreasing Chl-a, as most attenuation occurs in the blue part of the spectrum (Bricaud and Stramski, 1990), but this relation is not always linear as it depends on the pigment packaging effect and pigment composition (Shaju et al., 2015; Vishnu et al., 2018). The pigments in the algae include Chl-a and phycoerythrin, which absorb the energy from sunlight and drives photosynthesis (Siddiqui et al., 1991). The pigments contained in Trichodesmium are phycocyanin and phycoerythrin, and the absorption peaks are around 495, 545 and $565 \mathrm{~nm}$. This is different from the absorption peaks of diatoms, which peak around 443 and $685 \mathrm{~nm}$ (fluorescence) due to the presence of chlorophyll (Sarangi et al.,
2004). The spectral shape of phytoplankton absorption along with the remote sensing reflectance could be used for monitoring the fluctuation in phytoplankton composition at mariculture regions.

\section{Detrital absorption $\left(a_{d}\right)$}

In July, station C1 showed a high $a_{\mathrm{d}}$ value at $440 \mathrm{~nm}$ and station $\mathrm{P} 1$ showed low detrital absorption $0.035 \mathrm{~m}^{-1}$. During peak bloom the $a_{\mathrm{d}}(440)$ value showed a maximum of $0.85 \mathrm{~m}^{-1}$ and minimum of $0.031 \mathrm{~m}^{-1}$ at Gulf of Mannar. The detritus absorption spectra $\left(a_{\mathrm{d}}\right)$ during July and August at Gulf of Mannar and Palk Bay are given in Fig. 5. Detritus absorption spectra showed slight fluctuations at the wavelength of 508-511 nm and 646$653 \mathrm{~nm}$ at the peak bloom period and declining period of bloom. In July higher $a_{\mathrm{d}}$ value was observed at station C1 $\left(0.140 \mathrm{~m}^{-1}\right)$ and in August detritus absorption was very high during peak bloom $\left(0.085 \mathrm{~m}^{-1}\right)$ and declining period of bloom $\left(0.045 \mathrm{~m}^{-1}\right)$ at $440 \mathrm{~nm}$. The $a_{\mathrm{d}}$ value has direct relevance to the optical properties as the sediment particle interferes with the light absorption by Chl-a thus making the remote detection of the Trichodesmium blooms difficult due to optical complexity caused by sediment resuspension, coastal runoff, and bottom interference (Hu et al., 2010).

\section{Conclusions}

Phytoplankton bloom dominated by Trichodesmium was detected outside the fish culture cage during August in the Gulf of Mannar. Trichodesmium was present in less numbers in normal conditions in the study area. Stable salinity condition close to typical value of 35 psu and the depletion in nutrient concentration due to higher primary production has triggered the bloom of Trichodesmium. CDOM concentration was higher inside the fish culture cage, due to the accumulation of wastes from excretion of fishes and fish feed. The leaching of this organic matter to outside of fish culture cage resulted in high CDOM values outside of fish culture cage. During peak bloom and after bloom, near to mariculture cage showed higher Chl-a concentrations. During the bloom with high concentration of Chl-a does not lead to the high a*ph value could be attributed to the package effect. Throughout the study period centric diatoms dominated in this area except during bloom period and cyanobacteria identified during the study was Trichodesmium. The in-situ spectral measurement was a critical step towards ocean colour retrieval model development. Our study is a preliminary step to understand the in-situ biooptical characteristics of coastal waters of Gulf of Mannar and Palk Bay, which could lead to valuable insights in the accurate capture of water quality at this region. Continued efforts with direct measurements of in-situ bio-optical properties, such as backscattering and absorption coefficients and their relationships with remote-sensing reflectance $\left(R_{\mathrm{rs}}\right)$ are needed for the better performance of retrieval algorithms for water quality retrievals by remote sensing in these types of shallow and ecologically sensitive regions.

\section{Acknowledgements}

This study was funded by NF-POGO Alumni Network for Oceans (NANO) regional project "Study of Harmful Algal Blooms and other Aspects of Sardine Habitats around the Indian sub-continent (SHABASHI)", at Nansen environmental Research Centre India (NERCI). The first author thanks Partnership for Observation of Global Oceans (POGO) Secretariat, PML, UK for the fellowship during the study period. Authors wish to thank Director, Central Marine Fisheries Research Institute (CMFRI) for the help and facilities extended for conducting the study. The authors are grateful to the boat crew of CMFRI, Mandapam for the help during the sampling. We thankfully acknowledge Mr. Vishnu Narayanan, CMLRE for the help in plotting Figure 3. 

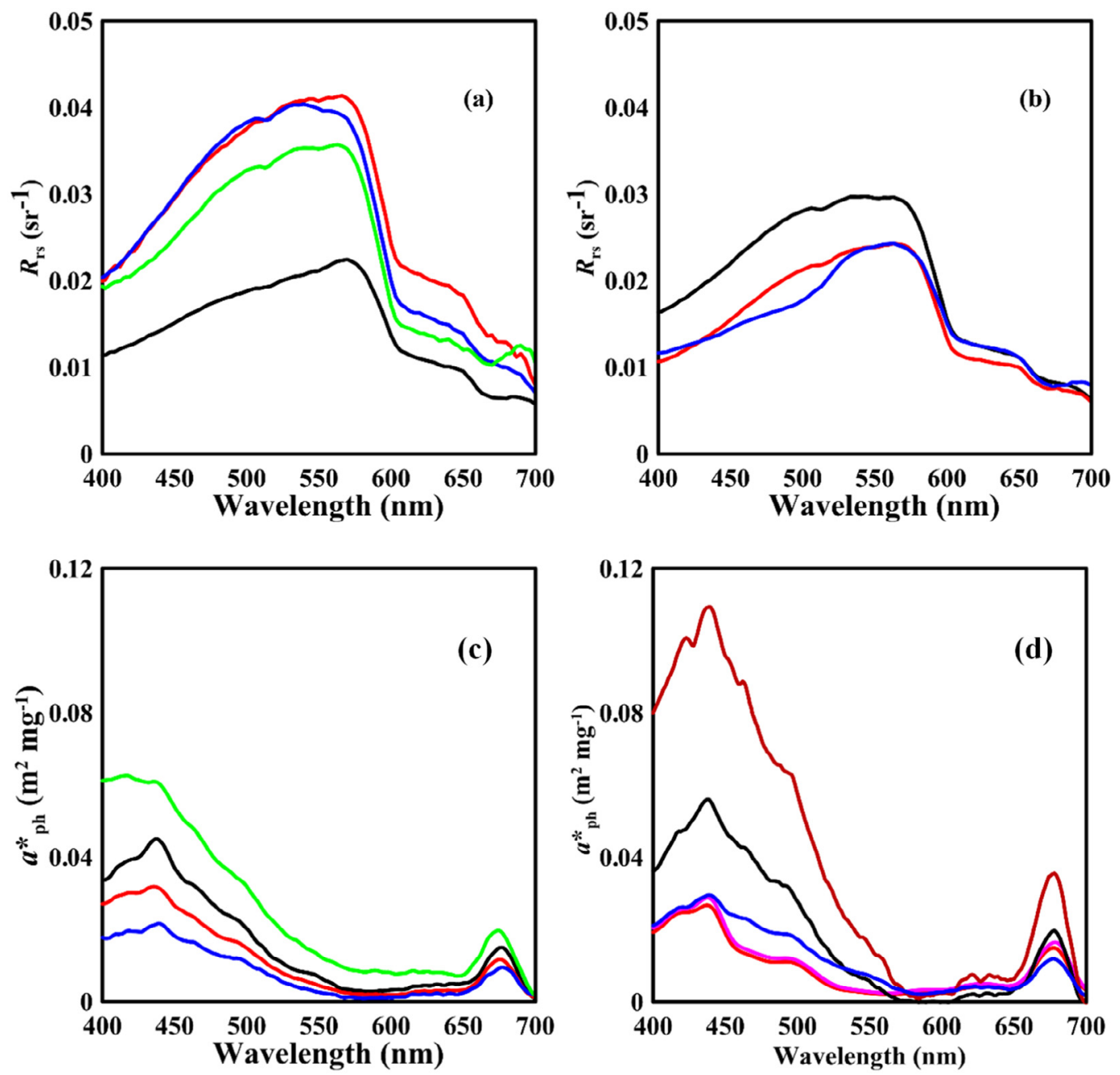

01

O1 Peak bloom

C1

O1 After bloom

G1

P1

Fig. 4. Remote-sensing reflectance spectra $\left(\mathrm{R}_{r s}\right)$ and Chlorophyll specific absorption Coefficient by phytoplankton $\left(\mathrm{a}^{*} \mathrm{ph}(\lambda)\right)$ recorded from the surface waters of Gulf of Mannar and Palk Bay during (a) July 2015 and (b) August 2015.

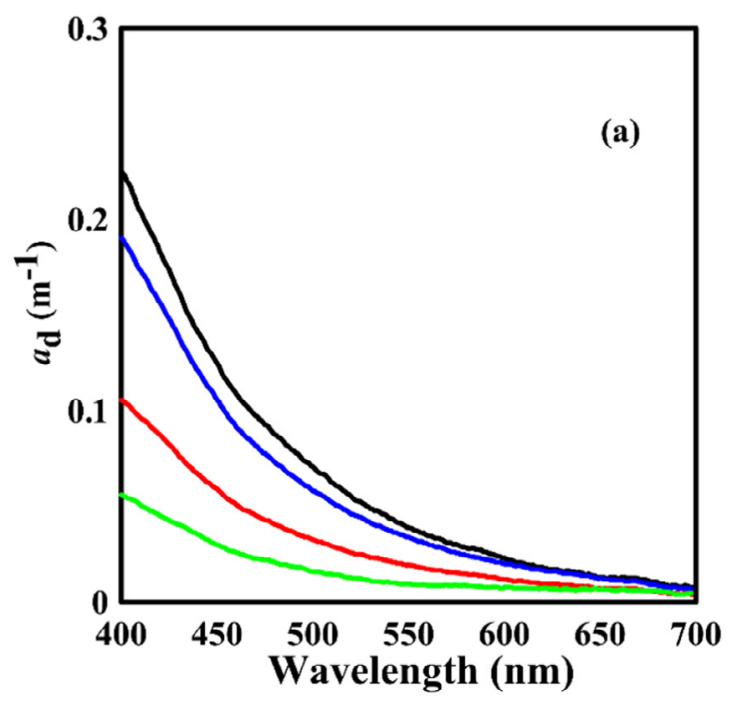

01

O1 Peak bloom

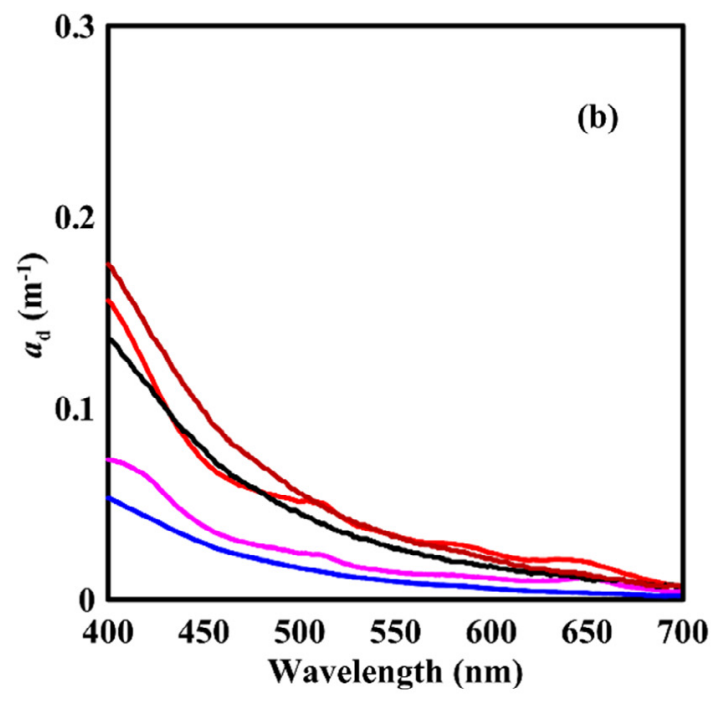

C1

O1 After bloom

G1

P1

Fig. 5. Spectral absorption coefficient of detritus $\left(a_{d}\right)$ measured from the surface waters of Gulf of Mannar and Palk Bay during (a) July 2015 and (b) August 2015. 


\section{References}

Anderson, D.M., Burkholde, J.M., Cochlan, W.P., Glibert, P.M., Gobler, C.J. Heil, C.A., Kudela, R.M., Parsons, M.L., Rensel, J.E.J., Townsend, D.W., Trainer, V.L., Vargo, G.A., 2008. Harmful algal blooms and eutrophication: Examining linkages from selected coastal regions of the United States. Harmful Algae 8, 39-53. http://dx.doi.org/10.1016/j.hal.2008.08.017.

Baskar, K., Sridhar, S.G.D. Sivakumar, T., Hussain, S.M., Maniyarasan, S., 2015. Temporal variation of physico-chemical parameters and ostracoda population, off Rameswaram, Gulf of Mannar, Southeast Coast of Tamil Nadu. India J. Geol. Soc. India 86, 663-670.

Beveridge, M., 2004. Cage Aquaculture, third ed. Blackwell Publishing, pp. 111-158.

Bindu, S., Muniyandi, K., 2005. Hydrographic parameters off Gulf of Mannar and Palk Bay during an year of abnormal rainfall. J. Mar. Biol. Assoc. India 47 (2), 198-200.

Borg, S., 2011. The impact of in-service teacher education on language teachers ' beliefs. System 39, 370-380. http://dx.doi.org/10.1016/j.system.2011.07.009.

Bricaud, A., Stramski, D., 1990. Spectral absorption coefficients of living phytoplankton and nonalgalbiogenous matter: A comparison between the Peru Upwelling area and Sargasso Sea. Limnol. Oceanogr. 35, 562-582.

Cleveland, .J.S., Weidemann, A.D., 1993. Quantifying absorption by aquatic particles: A multiple scattering correction for glass-fiber filters. Limnol. Oceanogr 38, 1321-1327. http://dx.doi.org/10.4319/lo.1993.38.6.1321.

Cloern, J.E., 2001. Our evolving conceptual model of the coastal eutrophication problem. Mar. Ecol. Prog. Ser. 210, 223-253.

Davidson, K., Gowen, R.J., Harrison, P.J., Fleming, L.E., Hoagland, P., Moschonas, G., 2014. Anthropogenic nutrients and harmful algae in coastal waters. J. Environ. Manage 146, 206-216. http://dx.doi.org/10.1016/j.jenvman.2014.07. 002.

Davidson, K., Miller, P., Wilding, T.A., Shutler, J., Bresnan, E., Kennington, K., Swan, S., 2009. A large and prolonged bloom of Karenia mikimotoi in Scottish waters in 2006. Harmful Algae 8 (2), 349-361. http://dx.doi.org/10.1016/j.hal. 2008.07.007.

Fargion, G.S., Mueller, J.L., 2000. NASA/TM-2000-209966 Ocean Optics Protocols For Satellite Ocean Color Sensor Validation, Revision 2 Goddard Sp. Flight Sp. Center, Greenbelt, Maryl: 1-184.

Galloway, J.N., Dentener, F.J., Capone, D.G., Boyer, E.W., Howarth, R.W., Seitzinger, S.P., Asner, G.P., Cleveland, C.C., Green, P.A., Holland, .E.A., Karl, D.M., Michaels, A.F., Porter, J.H., Townsend, A.R., Vorosmarty, C.J., 2004. Nitrogen cycles: past, present, and future. Biogeochemistry 70, 153-226.

Grasshoff, K., Kremling, K., Ehrhardt, M., 1999. Methods of Seawater Analysis, Third, Completely Revised and Extended ed. WILEY-VCH Verlag GmbH, D-69469 Weinheim (Federal Republic of Germany).

Grover, J.P., 1989. Effects of si:p supply ratio, supply variability and selective grazing in the plankton: an experiment with a natural algal and protistan assemblage. Limnol. Oceanogr. 34, 349-367.

Harrison, P.J., Davis, C.O., 1979. The use of outdoor phytoplankton continuous cultures to analyze factors influencing species selection. J. Exp. Mar. Biol. Ecol. 41, 9-23.

Hu, C., Cannizzaro, J., Carder, K.L., Muller-Karger, F.E., Hardy, R., 2010. Remote detection of trichodesmium blooms in optically complex coastal waters: Examples with MODIS full-spectral data. Remote Sens. Environ. 114 (9), 2048-2058.

ICES, 2002. Report of the Working Group on Environmental Interactions of Mariculture. ICES Headquarters, 8-12 April 2002.

Jagadeesan, L., Jyothibabu, R., Anjusha, A., Mohan, A.P., Madhu, N.V., Muraleedharan, K.R., Sudheesh, K., 2013. Ocean currents structuring the mesozooplankton in the Gulf of Mannar and the Palk Bay, southeast coast of India. Prog. Oceanogr. 110, 27-48.

Jyothibabu, R., Arya, P., Mohan, Jagadeesan, L., Anjusha, A., Muraleedharan, K.R., Lallu, K.R., Krishna, Kiran., Ullas, N., 2013. Ecology and trophic preference of picoplankton and nanoplankton in the Gulf of Mannar and the Palk Bay, southeast coast of India. J. Mar. Syst. 111-112, 29-44.

Jyothibabu, R., Madhu, N.V., Maheswaran, P.A., Jayalakshmy, K.V., Nair, K.K.C., 2008. Seasonal variation of microzooplankton $(20-200 \mu \mathrm{m})$ and its possible implications on the vertical carbon flux in the western Bay of Bengal. Cont. Shelf. Res. 28, 737-755. http://dx.doi.org/10.1016/j.csr.2007.12.011.

Karydis, M., Kitsiou, D., 2013. Marine water quality monitoring: A review. Mar. Pollut. Bull. 77, 23-36. http://dx.doi.org/10.1016/j.marpolbul.2013.09.012.

Kishino, M., Takahashi, M., Okami, N., Ichimura, S., 1985. Estimation of the spectral absorption coefficients of phytoplankton in a thermally stratified sea. Bull. Mar. Sci. 37, 634-642.

Kumar, K., Mella-Herrera, R.A., Golden, J.W.,

Kyewalyanga, M.N., Platt, T., Sathyendranath, S., Lutz, V.A., Stuart, V., 1998. Seasonal variations in physiological parameters of phytoplankton across the North Atlantic. J. Plankton. Res. 20, 17-42.

Lee, Z.P., Du, K., Voss, K.J., Zibordi, G., Lubac, B., Weidemann, R., Arnone, A., 2011. An inherent-optical-property-centered approach to correct the angular effects in water-leaving radiance. Appl. Opt. 50, 3155-3167. http://dx.doi.org/ $10.1364 /$ AO.50.003155.
Lubac, B., Loisel, H., 2007. Variability and classification of remote sensing reflectance spectra in the eastern English Channel and southern North Sea. Remote Sens. Environ. 110, 45-58. http://dx.doi.org/10.1016/j.rse.2007.02. 012 .

Menon, H.B., Sangekar, N.P., Lotlikker, A.A., Vethamony, P., 2011. Dynamics of chromophoric dissolved organic matter in Mandovi and Zuari estuaries -A study through in situ and satellite data. ISPRS J. Photogramm. Remote Sens. 66 (4), 545-552.

Minu, P., Lotliker, A.A., Shaju, S.S., SanthoshKumar, B., Ashraf, P.M., Meenakumari, B., 2014. Effect of optically active substances and atmospheric correction schemes on remote-sensing reflectance at a coastal site off Kochi. Int. J. Remote Sens. 35, 5434-5447. http://dx.doi.org/10.1080/01431161.2014. 926420.

Mires, D., 1999. Preparation and implementation of fisheries policy in relation to aquatic genetic resources. In: Pullin, R.S.V., Bartley, D.M., Kooiman, J. (Eds.) Towards policies for conservation and sustainable use of aquatic genetic resources. ICLARM Conf. Proc.. pp. 63-72.

Mitbavkar, S., Anil, A.C., 2011. Tiniest primary producers in the marine environment: an appraisal from the context of waters around India. Current Sci. 100 (7), 986-988.

Mitchell, G., Holm-Hansen, O.B., 1991. Bio-optical properties of Antarctic Peninsula waters: differentiation from temperate ocean models. Deep Sea Res. Part A 38, 8-9, 1009-1028, http://dx.doi.org/10.1016/0198-0149(91)90094-V.

Mitchell, M., Kahru, J., Wieland, Stramska, M., 2003. Determination of spectral absorption coefficients of particles, dissolved materials and phytoplankton for discrete water samples in Ocean Optics Protocols For Satellite Ocean Color Sensor Validation, Revision 4, Volume 4: Inherent optical properties: instruments, characterization, field measurements and data analysis protocols. NASATech. Rep., Greenbelt, Maryland.

Mohanty, A.K., Satpathy, K.K., Sahu, G., Hussain, K.J., Prasad, M.V.R., Sarkar, S.K. 2010. Bloom of Trichodesmiumerythraeum and its impacts on water quality and plankton community structure in the coastal waters of southeast coast of India. Indian J. Mar. Sci. 39 (3), 323-333.

Murtugudde, R.G., Signorini, S.R., Christian, J.R., Busalacchi, A.J., McClain, C.R., Picaut, J., 1999. Ocean color variability of the tropical Indo-Pacific basin observed by SeaWiFS during 1997-1998. J. Geophys. Res. 104 (C8), 18351-18366.

Paerl, H.W., Dyble, J., Moisander, P.H., Noble, R.T., Piehler, M.F., Pinckney, J.L. Steppe, T.F., Twomey, L., Valdes, L.M., 2003. Microbial indicators of aquatic ecosystem change: current applications to eutrophication studies. FEMS Microbiol. Ecol. 46, 233-246. http://dx.doi.org/10.1016/S0168-6496(03)002009.

Pandi, S.R., Gundala, C., Rayaprolu, K., Naroju, V.H., Rallabhandi, M., Balivada, S. A.A. Lotliker, N.S. Sarma, 2017. Contrasting bio-optical characteristics of coastal water prior to and in the aftermath of a tropical super cyclone. Int. J. Remote Sens. 38 (12), 3519-3530. http://dx.doi.org/10.1080/01431161.2017. 1297546.

Pandi, S.R., Kiran, R., Sarma, N.S., Srikanth, A.S., .Sarma, V.V.S.S., Krishna, D. Prasad, V.R., Acharyya, T., Reddy, K.G., 2013. Contrasting phytoplankton community structure and associated light absorption characteristics of the western Bay of Bengal. Ocean Dyn. 64, 89-101. http://dx.doi.org/10.1007/ s10236-013-0678-1.

Purvaja, R., Robin, R.S., Ganguly, D., Hariharan, G., Singh, G., Raghuraman, R. Ramesh, R., 2018. Seagrass meadows as proxy for assessment of ecosystem health. Ocean Coast. Manag. 159, 34-45.

Ramachandran, S., Ramesh, D.A., Gowri, V.S., 2000. Coastal ecosystems: Their problems and management. In: Management of Problems in Coastal Area Ocean Engineering Center. pp. 170-185.

Rao, D.V.S., Srinivasa Rao, K., Iyer, C.S.P., Chittibabu, P., 2008. Possible ecological con-sequences from the SethuSamudram Canal Project. India. Mar. Pollut. Bull 56, 170-186.

Sarangi, R.K., Chauhan, P., Nayak, S.R., 2004. Detection and monitoring of Trichodesmium blooms in the coastal waters off Saurashtra coast, India using IRS-P4 OCM data. Current Science, pp. 1636-1641.

Shaju, S.S., Minu, P., Srikanth, A.S., Ashraf, P.M., Vijayan, A.K., Meenakumari, B. 2015. Decomposition study of in vivo phytoplankton absorption spectra to identify the pigments and phytoplankton group in complex case 2 waters of coastal Arabian Sea. Oceanol. Hydrobiol. Stud. 44 (3), 1-12.

Shankar, D., Vinayachandran, P.N., Unnikrishnan, A.S., 2002. The monsoon currents in the north Indian Ocean. Prog. Oceanogr. 52 (1), 63-120.

Siddiqui, P.J.A., Carpenter, E.J., Bergman, B., Rueter, J.G., 1991. Trichodesmium: Ultrastructure and Protein Localization. Kluwer Academic Publishers, Dordrecht.

Sridhar, R., Thangaradjou, T., Kannan, L., 2010. Spatial and temporal variations in phytoplankton in coral reef and seagrass ecosystems of the Palk Bay southeast coast of India. J. Environ. Biol 31 (5), 765-771.

Tett, P., Carreira, C., Mills, D.K., Van Leeuwen, S., Foden, J., Bresnan, E., Gowen, R.J. 2008. Use of a phytoplankton community index to assess the health of coastal waters. ICES J. Mar. Sci. 65 (8), 1475-1482. 
Tilstone, G.H., Lotliker, A.A., Miller, P.I., Ashraf, P.M., Kumar, T.S., Suresh, T. Ragavan, B.R., Menon, H.B., 2013. Assessment of MODIS-Aqua chlorophylla algorithms in coastal and shelf waters of the eastern Arabian Sea. Cont. Shelf Res. 65, 14-26. http://dx.doi.org/10.1016/j.csr.2013.06.003.

Vinayachandran, P.N., Kagimoto, T., Masumoto, Y., Chauhan, P., Nayak, S.R., Yamagata, T., 2005. Bifurcation of the East India Coastal Current east of Sri Lanka. Geophys. Res. Lett. 32 (L15606), http://dx.doi.org/10.1029/2005GL022864.

Vishnu, P.S., Shaju, S.S., Tiwari, S.P., Menon, Nandini, Nashad, M., Ajith Joseph, C. Raman, Mini, Hatha, Mohamed, Prabhakaran, M.P., Mohandas, A., 2018. Seasonal variability in bio-optical properties along the coastal waters off Cochin. Int. J. Appl. Earth Obs. Geoinform. 66, 184-195.
Welschmeyer, N.A., 1985. Fluorometric analysis of chlorophyll a in the presence of chlorophyll b and pheopigments. Limnol. Oceanogr. 39, http://dx.doi.org/ 10.4319/lo.1994.39.8.1985.

Yapa, K.K.S., 2000. Seasonal variability of sea surface chlorophyll-a of waters around Sri Lanka. Proc. Indian Acad. Sci. 109, 427-432.

Zhang, X., Stavn, R.H., Falster, A.U., Gray, D., Gould, R.W., 2014. New insight into particulate mineral and organic matter in coastal ocean waters through optical inversion. Estuar. Coast. Shelf Sci. 149, 1-12. http://dx.doi.org/10. 1016/j.ecss.2014.06.003.

Zhao, J., Cao, W., Wang, G., Yang, D., Yang, Y., Sun, Z., Zhou, W., Liang, S., 2009. The variation in optical properties of CDOM throughout an algal bloom event. Estuar. Coast. Shelf Sci. 82, 225-232. 